\title{
Effect of Zn Application on Root Growth Parameters and Shoot Dry Matter Content of Some Cowpea Genotypes
}

\author{
Santosh Chandra Bhatt ${ }^{1}$, Deepa Rawat $^{2}$ and Prakash Chandra Srivastava ${ }^{1}$ \\ ${ }^{1}$ Govind Ballabh Pant University of Agriculture and Technology, \\ Pantnagar, 263145, Uttarakhand, India \\ ${ }^{2}$ Department of Soil Science, College of Forestry, Ranichauri, \\ Dist. Tehri Garhwal, VCG, India \\ *Corresponding author
}

\begin{abstract}
A B S T R A C T
Keywords

Zinc, Cowpea genotypes,

Root and shoot characteristics

Article Info

Accepted:

12 March 2019

Available Online:

10 April 2019

A Pot experiment was conducted with nine cowpea genotypes and two levels of zinc in sand culture medium to study the response of different cowpea genotypes to zinc fertilization in root characteristics. The highest average total root length $(944.9 \mathrm{~cm})$, surface area $\left(227.4 \mathrm{~cm}^{2}\right)$, diameter $(0.75 \mathrm{~mm})$ and root volume $\left(0.71 \mathrm{~cm}^{3}\right)$ were recorded in $\mathrm{V} 1$. The highest average number of root tips was observed in V11 (1676.1). The highest average number of forks (7085.0) and number of crossings (1194.8) was noted in V10. The highest average cation exchange capacity of roots $(0.398$ meq $\mathrm{g}^{-1}$ ) was recorded in V5.
\end{abstract}

\section{Introduction}

Zinc is essential for the normal healthy growth and reproduction of plants. Plants absorb $\mathrm{Zn}$ as zinc ions $\left(\mathrm{Zn}^{+2}\right)$. Zinc sufficient plants contain 27 to $150 \mathrm{ppm} \mathrm{Zn}$ in mature tissues. Zinc plays a key role as a structural constituent or regulatory co-factor of a wide range of different enzymes and proteins in many important biochemical pathways and these are mainly concerned with: carbohydrate metabolism, both in photosynthesis and in the conversion of sugars to starch, protein metabolism, auxin (growth regulator) metabolism, pollen formation, the maintenance of the integrity of biological membranes, the resistance to infection by certain pathogens. Alloway (2004) reported that zinc is one of the trace elements which are essential for the normal healthy growth and reproduction of crop plants.

Differential responses of plants to $\mathrm{Zn}$ deficiency indicate the existence of genotypic variation for efficient utilization of native soil zinc. Genotypic variations in $\mathrm{Zn}$ efficiency have been associated with different mechanisms operating within the plant and in the rhizosphere. Some plant genotypes possess mechanisms for 
efficient acquisition of $\mathrm{Zn}$ from soils low in $\mathrm{Zn}$. These mechanisms include: increased $\mathrm{Zn}$ bioavailability in the rhizosphere due to release of root exudates, higher $\mathrm{Zn}$ uptake by roots, and efficient utilization and (re)-translocation of $\mathrm{Zn}$ (Hart et al., 1998). In the present study, we attempted to identify genotypic variability in terms of accumulation and utilization of zinc for plant growth by studying the root parameters of some cowpea genotypes.

\section{Materials and Methods}

A bulk sample of quartz sand was thoroughly screened and washed several times in tap water to remove dirt. Finally, the quartz sand was soaked in dilute $\mathrm{HCl}$ and repeatedly washed by deionized water till the effluent water reached a $\mathrm{pH}$ around 6.0 and finally kept for air-drying. After air-drying, sand was filled in $1 / 2 \mathrm{~kg}$ plastic pots. The experiment was laid in a completely randomized design replicated twice with two level of $\mathrm{Zn}$ ( i) + Zn: $0.05 \mathrm{mg} \mathrm{L}^{-1}$, ii) $-\mathrm{Zn}: 0.0$ $\mathrm{mg} \mathrm{L}^{-1}$ ).

Seeds of nine contrasting cowpea genotypes (V1, V2, V3, V5, V6, V7, V9, V10 and V11) were pre-germinated in towel paper in a seed germinator. Three pre-germinated seedlings (4 days old) of each genotype were transplanted to the pots in duplicate under green house conditions. For the next few days, the pots were watered with distilled water to keep them moistened. The details of genotypes selected for study were V1= Pant Lobia-1 (IT 205-1), V2= Pant Lobia-2 (IT1042-3), V3 = Pant Lobia-3 (IT889-1), V5 $=$ PGCP 12 (IT 82E-18), V6 = PGCP 15(PL$10 \mathrm{~K} 1-1-4-1-3), \mathrm{V} 7=\mathrm{PGCP} 16(\mathrm{PGCP}-5 \times$ PGCP-1), V9= PGCP-32(PGCP-3 × PGCP-6 13), $\mathrm{V} 10=\mathrm{PGCP}-33(\mathrm{PGCP}-8 \times \mathrm{PGCP}-22)$ and V11= PGCP-34 (PGCP-12 × PGCP-417). Prior to preparation of Hoagland solution, the stock solutions of $\mathrm{NH}_{4} \mathrm{NO}_{3}$, $\mathrm{CaCl}_{2} .2 \mathrm{H}_{2} \mathrm{O}, \mathrm{KNO}_{3}, \mathrm{KH}_{2} \mathrm{PO}_{4}, \mathrm{MgSO}_{4} \cdot 7 \mathrm{H}_{2} \mathrm{O}$ were made by taking 80, 147.1, 101.1, 136.1 and $246.5 \mathrm{~g} \mathrm{~L} \mathrm{~L}^{-1}$ respectively and stock solution of tracer elements $\mathrm{H}_{3} \mathrm{BO}_{3}$, $\mathrm{MnCl}_{2} .4 \mathrm{H}_{2} \mathrm{O}, \mathrm{ZnSO}_{4} .7 \mathrm{H}_{2} \mathrm{O}, \mathrm{CuSO}_{4} .5 \mathrm{H}_{2} \mathrm{O}$ and $\mathrm{NaMoO}_{4}$ were prepared by taking 2.8, 1.8, $0.05,0.1$ and $0.025 \mathrm{~g} \mathrm{~L}^{-1}$ respectively. To prepare Fe-EDTA solution, the $\mathrm{pH}$ of $\mathrm{KOH}$ solution (56.1 $\mathrm{g} \mathrm{L}^{-1}$ ) was adjusted to 5.5 using $\mathrm{H}_{2} \mathrm{SO}_{4}$ and then EDTA.2Na (10.4 g) and FeSO4.7H2O (7.8 g) were added to it and diluted to $1 \mathrm{~L}$. This solution was considered as Fe-EDTA. The following amounts of stock solutions were added in $1 \mathrm{~L}$ volumetric flask and $\mathrm{pH}$ was adjusted to 7.0 using $\mathrm{Ca}(\mathrm{OH})_{2}$ and then diluted to $1 \mathrm{~L}$ with distilled water to get the nutrient solution (Hoagland solution). $\mathrm{NH}_{4} \mathrm{NO}_{3}=6 \mathrm{~mL}, \mathrm{CaCl}_{2} .2 \mathrm{H}_{2} \mathrm{O}=7 \mathrm{~mL}, \mathrm{KNO}_{3}$ $=5 \mathrm{~mL}, \mathrm{KH}_{2} \mathrm{PO}_{4}=2 \mathrm{~mL}, \mathrm{MgSO}_{4} .7 \mathrm{H}_{2} \mathrm{O}=2$ $\mathrm{mL}$, Trace elements $=1 \mathrm{~mL}$ and Fe-EDTA $=$ $1 \mathrm{~mL}$. This solution was designated as ' $+\mathrm{Zn}$ ' and when this solution prepared without $\mathrm{ZnSO}_{4} .7 \mathrm{H}_{2} \mathrm{O}$ it was designated as '- $\mathrm{Zn}$ '.

A $40 \mathrm{~mL}$ of ' $+\mathrm{Zn}$ ' and ' $-\mathrm{Zn}$ ' Hoagland solution was added to the pots on 5 days after transplanting (DAT). The application of Hoagland solution was practiced three times a week and continued till the crop attained physiological maturity and then at this growth stage plants were uprooted for chemical analysis in roots and shoots. Uprooted plants were thoroughly and sequentially washed, first with tap water then in dilute $\mathrm{HCl}(0.1 \mathrm{~N})$ and finally in deionized water. The roots were separated from shoots. Roots and shoots were soaked between bloating paper to remove moisture and their fresh weights were recorded. Washed plant roots were stored in refrigerator until scanned by scanner and one root sample of each cowpea genotype was stored in deep freezer for the estimation of root cation exchange capacity. Plant shoots and remaining roots samples were kept for oven drying at $60^{\circ} \mathrm{C}$ for $48 \mathrm{~h}$. The oven dry weight of shoots and roots were recorded for each pot. The oven dried root and shoot samples were finally crushed with the help of 
pestle and mortar and stored in paper-bags for chemical analysis. The details of chemical analysis performed are given below. The oven dry weight of shoots and roots were recorded for each pot. The oven dried root and shoot samples were finally crushed with the help of pestle and mortar and stored in paper-bags for chemical analysis.

\section{Results and Discussion}

\section{Root length}

The data on total root length $(\mathrm{cm})$ of all nine cowpea genotypes both under application of $\mathrm{Zn}(+\mathrm{Zn})$ and no application of $\mathrm{Zn}(-\mathrm{Zn})$ are presented in Table 1.

It is clearly seen from the data that the highest average total root length $(944.9 \mathrm{~cm})$ was recorded in V1 while it was lowest in V9 $(475 \mathrm{~cm})$. The average total root length observed in V9 was at par with that of V2, V6 and V11.The main effect of $\mathrm{Zn}$ application indicated that application of $\mathrm{Zn}$ increased the average total root length significantly by 22.5 percent over no application of $\mathrm{Zn}$. The interaction effect of genotypes and $\mathrm{Zn}$ level $(\mathrm{V} \times \mathrm{Zn})$ had no statistically significant effect on total root length.

\section{Surface area}

The data on surface area of root $\left(\mathrm{cm}^{2}\right)$ of all nine cowpea genotypes under application of $\mathrm{Zn}(+\mathrm{Zn})$ and no application of $\mathrm{Zn}(-\mathrm{Zn})$ are presented in Table 2.

The data contained in the Table 4 clearly indicate that the highest average surface area of root was recorded in V1 with a value of $227.4 \mathrm{~cm}^{2}$ while it was the lowest $\left(64.8 \mathrm{~cm}^{2}\right)$ in V9. The average surface area of root noted in V9 was at par with that of V2, V6, V7, $\mathrm{V} 10$ and V11. The main effect of $\mathrm{Zn}$ level indicated that application of Zn significantly increased the mean surface area of roots in all cowpea genotypes by 43.8 percent over no application of $\mathrm{Zn}$. The interaction effect of genotypes and $\mathrm{Zn}$ levels $(\mathrm{V} \times \mathrm{Zn})$ had no statistically significant effect on root surface area.

\section{Root diameter}

The data pertaining to effect of $\mathrm{Zn}$ application on average diameter of root $(\mathrm{mm})$ of all nine cowpea genotypes are presented in Table 3.

It is evident from the data that the highest average root diameter was recorded in V1 $(0.75 \mathrm{~mm})$ while it was the lowest $(0.41 \mathrm{~mm})$ in V11.

The average root diameter noted in V11 was at par with V2, V5, V6, V7, V9 and V10. The main effect of $\mathrm{Zn}$ levels on the average root diameter was statistically non-significant. The interaction effect of genotypes and $\mathrm{Zn}$ levels $(\mathrm{V} \times \mathrm{Zn})$ also had no statistically significant effect on the average root diameter.

\section{Root volume}

The data pertaining to effect of $\mathrm{Zn}$ application on root volume of all nine cowpea genotypes are presented in Table 4.

The data presented in Table 6 clearly indicate that the highest average root volume (4.66 $\mathrm{cm}^{3}$ ) was recorded in V1 while it was lowest inV9 $\left(0.71 \mathrm{~cm}^{3}\right)$. The average root volume observed in V9 was at par with V2, V5, V6, V7, V10 and V11. As regard the main effect of $\mathrm{Zn}$ levels, application of $\mathrm{Zn}$ increased the average root volume significantly by 72.1 percent over no application of $\mathrm{Zn}$.

The interaction effect of genotypes and $\mathrm{Zn}$ levels $(\mathrm{V} \times \mathrm{Zn})$ had no statistically significant effect on root volume. 


\section{Root tips}

The data on effect of $\mathrm{Zn}$ application on the number of root tips in all cowpea genotypes are presented in Table 5.

It is evident from the data that the highest average number of root tips was recorded in V11 (1676.1) while it was lowest (983.5) in V9. The main effect of zinc levels had no statistically significant effect on number of root tips in all cowpea genotypes. The interaction effect of zinc levels and genotypes $(\mathrm{V} \times \mathrm{Zn})$ had no statistically significant influence on number of root tips in cowpea genotypes.

\section{Number of forks}

The data on effect of $\mathrm{Zn}$ application on the number of forks in roots of all nine cowpea genotypes are presented in Table 6.

It is evident from the data that the highest average number of forks (7085.0) was observed in V10 while it was the lowest in V9 (4297.1). The average number of forks recorded in roots of V9 was at par with V2, V3, V5, V6 and V11. The main effect of zinc levels indicated that $\mathrm{Zn}$ application increased the average number of forks in roots of cowpea genotypes significantly by 16.2 percent over no application of zinc. The interaction effect of zinc levels and genotypes $(\mathrm{V} \times \mathrm{Zn})$ had no statistically significant effect on number of forks in roots of cowpea genotypes.

\section{Number of crossings}

The data on numbers of crossings in roots of all nine cowpea genotypes under the application of $\mathrm{Zn}(+\mathrm{Zn})$ and no application of $\mathrm{Zn}(-\mathrm{Zn})$ are presented in Table 7. The data contained in Table 9 clearly indicated that the highest average number of crossings (1194.8) was recorded in V10 while it was the lowest (716.4) in V9. The number of crossing noted in V9 was at par with V1, V2, V3, V5, V6 and V7. The main effect of $\mathrm{Zn}$ levels on the average number of crossings in roots of cowpea genotypes was statistically not significant. The interaction effect of zinc levels and genotypes $(\mathrm{V} \times \mathrm{Zn})$ had no statistically significant influence on number of crossings in roots of cowpea genotypes

\section{Cation exchange capacity}

The data on root cation exchange capacity of all nine cowpea genotypes under the application of $\mathrm{Zn}(+\mathrm{Zn})$ and no application of $\mathrm{Zn}(-\mathrm{Zn})$ are presented in Table 8.

The data clearly indicated that the highest average cation exchange capacity of roots $\left(0.398 \mathrm{meq} \mathrm{g}^{-1}\right)$ was recorded in V5 while it was lowest $\left(0.317 \mathrm{meq} \mathrm{g}^{-1}\right)$ noted in V2. The average root cation exchange capacity noted in V2 was at par with V1, V3, V6 and V10. The average root cation exchange capacity values observed for V1 and V10 were numerically similar. As regard the main effect of zinc levels, $\mathrm{Zn}$ application decreased the average root cation exchange capacity significantly by 8.2 percent over no application of zinc. The interaction effect of genotypes and zinc levels $(\mathrm{V} \times \mathrm{Zn})$ had statistically significant effect on root cation exchange capacity of cowpea genotypes. In the case of V9, the application of zinc brought a significant increase in root cation exchange capacity while in case of genotypes V5, V6 and V7, application of zinc significantly decreased the root exchange capacity in comparison to no application of zinc.

\section{Root weight per plant}

The data on root weight per plant (g) of all nine cowpea genotypes under the application of $\mathrm{Zn}(+\mathrm{Zn})$ and no application of $\mathrm{Zn}(-\mathrm{Zn})$ 
are presented in Table 9. It is evident from the data that the highest mean root weight per plant $(0.190 \mathrm{~g})$ was recorded in V10 while it was the lowest $(0.105 \mathrm{~g})$ in V2. The main effect of zinc levels had no statistically significant effect on the average root weight per plant. The interaction of genotypes and zinc levels $(\mathrm{V} \times \mathrm{Zn})$ had statistically significant effect on root weight per plant. In the case of V6 and V9, $\mathrm{Zn}$ application increased the root weight per plant by 14.1 and 26.1 percent over no application of zinc, respectively. On the other hand, in the case of $\mathrm{V} 1, \mathrm{Zn}$ application decreased the root weight per plant by 21.3 percent in comparison to no application of zinc.

\section{Shoot weight per plant}

The data on shoot weight per plant (g) of nine cowpea genotypes under different $\mathrm{Zn}$ levels are presented in Table 10. It is evident from the data that the highest average shoot weight per plant $(0.92 \mathrm{~g})$ was recorded in V6 while the lowest average shoot weight per plant $(0.49 \mathrm{~g})$ was in V2. The average shoot weight per plant recorded in V2 was at par with V11. As regard the main effect of zinc levels, $\mathrm{Zn}$ application increased the average shoot weight per plant significantly by 11.6 percent over no application of zinc. The interaction effect of genotypes and zinc levels $(\mathrm{V} \times \mathrm{Zn})$ had statistically significant effect on shoot weight per plant. A close perusal of data revealed that in case of genotypes V3, V6 and V9 the application of zinc significantly increased the shoot weight per plant while in rest of genotypes (V1, V2, V5, V7, V10 and V11) the shoot weight per plant was not significantly influenced by the application of zinc in comparison to no application of zinc.

\section{Dry weight ratio in shoot and root}

The data on dry weight ratio in shoot and root (g) of all nine cowpea genotypes under different Zn levels are presented in Table 11. It clearly apparent from the data that the highest average dry weight ratio in shoot and root $(5.50 \mathrm{~g})$ was recorded in V6 while it was the lowest in V11 (4.02 g). The average dry weight ratio in shoot and root noted in V11 was at par with V5. As regard the main effect of zinc levels, application of $\mathrm{Zn}$ increased the average dry weight ratio in shoot and root significantly by 10.9 percent in comparison to no application of zinc. The interaction effect of zinc levels and genotypes had statistically significant influence on dry weight ratio in shoot and root of cowpea genotypes. A close perusal of data revealed that application of zinc increased the dry weight ratio in shoot and root significantly in genotypes V1, V3 and V10 in comparison to no application of zinc while genotype V7 showed a slight decrease in the dry weight ratio in shoot and root with the application of $\mathrm{Zn}$ in comparison to no application of zinc.

As a rule under nutrient efficiency, the acquisition of nutrients by the roots plays the most important role (Gutschick, 1993). Efficiency in acquisition largely depends on root size and morphology. A large surface area (fine roots, long root hairs) is either an inherent property (e.g., grasses vs. legumes) or deficiency-induced trait (e.g., by $\mathrm{P}$ or $\mathrm{N}$, but not $\mathrm{K}$ or $\mathrm{Mg}$ deficiency). It is of key importance for acquisition particularly of $\mathrm{P}$, and most likely also ammonium, in upland soils (Marschner, 1998).

A significant effect of $\mathrm{Zn}$ application on average root length of cowpea with the application of $\mathrm{Zn}$ over no application of $\mathrm{Zn}$ showed that zinc is required for the synthesis of tryptophan, which is most likely precursor for the biosynthesis of IAA and responsible for growth parameters. Impairment in auxin synthesis in plants might be either due to decreased synthesis of IAA or enhanced oxidative degradation of IAA by reactive 
oxygen species produced under $\mathrm{Zn}$-deficient conditions in the plants (Robson, 1994 and Cakmak, 2011). Singh and Bhatt (2013) also reported that $\mathrm{Zn}$ application increased the root length. They observed 53.2 percent increment in root length with the foliar application of 0.08 percent $\mathrm{Zn}$ over no application of $\mathrm{Zn}$. Chen et al., (2009) reported from their study that Zn efficiency was closely associated with a larger surface area (longer fine root and larger root surface). Further, they concluded that under moderate $\mathrm{Zn}$ deficient stress, fine root development of the efficient genotype was enhanced, and the greater surface area could help an increase the plant's ability to acquire $\mathrm{Zn}$ from soil.

Table.1 Effect of $\mathrm{Zn}$ application on total root length $(\mathrm{cm})$ of cowpea genotypes

\begin{tabular}{|c|c|c|c|}
\hline \multirow{2}{*}{ Genotypes } & \multicolumn{3}{|c|}{ Average total root length (cm) } \\
\hline & $\mathbf{+ Z n}$ & $\mathbf{- Z n}$ & Mean \\
\hline V1 & 1101.2 & 788.6 & 944.9 \\
\hline V2 & 726.1 & 562.7 & 644.4 \\
\hline V3 & 773.1 & 633.9 & 703.5 \\
\hline V5 & 813.3 & 610.2 & 711.7 \\
\hline V6 & 623.7 & 504.8 & 564.2 \\
\hline V7 & 724.4 & 672.4 & 698.4 \\
\hline V9 & 604.0 & 347.5 & 475.7 \\
\hline V10 & 729.2 & 828.6 & 778.9 \\
\hline V11 & 686.2 & 593.1 & 639.7 \\
\hline Mean & 753.4 & 615.8 & 684.6 \\
\hline Effect & $\mathbf{V}$ & $\mathbf{Z n ~ l e v e l s}$ & $\mathbf{V} \times \mathbf{Z n ~ l e v e l s}$ \\
\hline S.Em. \pm & 65.9 & 31.1 & 93.2 \\
\hline C.D. $(\mathbf{p} \leq \mathbf{0 . 0 5})$ & 186.8 & 88.1 & $\mathrm{NS}$ \\
\hline
\end{tabular}

Table.2 Effect of $\mathrm{Zn}$ application on surface area $(\mathrm{cm} 2)$ of cowpea genotypes

\begin{tabular}{|c|c|c|c|}
\hline \multirow[t]{2}{*}{ Genotypes } & \multicolumn{3}{|c|}{ Surface area of root $\left(\mathrm{cm}^{2}\right)$} \\
\hline & $+\mathbf{Z n}$ & $-\mathbf{Z n}$ & Mean \\
\hline V1 & 297.1 & 157.7 & 227.4 \\
\hline V2 & 116.3 & 82.5 & 99.4 \\
\hline V3 & 160.3 & 110.1 & 135.2 \\
\hline V5 & 156.1 & 94.6 & 125.4 \\
\hline V6 & 85.6 & 102.1 & 93.9 \\
\hline V7 & 133.5 & 88.8 & 111.2 \\
\hline V9 & 85.6 & 43.9 & 64.8 \\
\hline V10 & 108.4 & 115.5 & 111.9 \\
\hline V11 & 95.3 & 72.6 & 83.9 \\
\hline Mean & 137.6 & 96.4 & 117.0 \\
\hline Effect & $\mathbf{V}$ & Zn levels & $\mathrm{V} \times \mathrm{Zn}$ levels \\
\hline S.Em. \pm & 18.5 & 8.7 & 26.2 \\
\hline C.D. $(p \leq 0.05)$ & 52.6 & 24.8 & NS \\
\hline
\end{tabular}


Table.3 Effect of $\mathrm{Zn}$ application on average root diameter $(\mathrm{mm})$ of cowpea genotypes

\begin{tabular}{|c|c|c|c|}
\hline \multirow{2}{*}{ Genotypes } & \multicolumn{3}{|c|}{ Average root diameter $(\mathbf{m m})$} \\
\hline & $\mathbf{+ Z n}$ & $\mathbf{- Z n}$ & Mean \\
\hline V1 & 0.86 & 0.63 & 0.75 \\
\hline V2 & 0.51 & 0.46 & 0.49 \\
\hline V3 & 0.63 & 0.56 & 0.59 \\
\hline V5 & 0.60 & 0.49 & 0.54 \\
\hline V6 & 0.43 & 0.61 & 0.52 \\
\hline V7 & 0.54 & 0.42 & 0.48 \\
\hline V9 & 0.44 & 0.41 & 0.42 \\
\hline V10 & 0.45 & 0.44 & 0.45 \\
\hline V11 & 0.42 & 0.39 & 0.41 \\
\hline Mean & 0.54 & 0.49 & 0.52 \\
\hline Effect & $\mathbf{V}$ & $\mathbf{Z n}$ levels & $\mathbf{V} \times \mathbf{Z n}$ levels \\
\hline S.Em. \pm & 0.05 & 0.02 & 0.07 \\
\hline C.D. $(\mathbf{p} \leq \mathbf{0 . 0 5})$ & 0.14 & NS & NS \\
\hline
\end{tabular}

Table.4 Effect of Zn application on root volume (cm3) of cowpea genotypes

\begin{tabular}{|c|c|c|c|}
\hline \multirow[t]{2}{*}{ Genotypes } & \multicolumn{3}{|c|}{ Root volume $\left(\mathrm{cm}^{3}\right)$} \\
\hline & $+\mathbf{Z n}$ & $-\mathbf{Z n}$ & Mean \\
\hline V1 & 6.70 & 2.62 & 4.66 \\
\hline V2 & 1.51 & 0.97 & 1.24 \\
\hline V3 & 2.89 & 1.55 & 2.22 \\
\hline V5 & 2.44 & 1.19 & 1.82 \\
\hline V6 & 0.94 & 2.00 & 1.47 \\
\hline V7 & 2.35 & 0.93 & 1.64 \\
\hline V9 & 0.98 & 0.44 & 0.71 \\
\hline V10 & 1.30 & 1.29 & 1.30 \\
\hline V11 & 1.06 & 0.71 & 0.89 \\
\hline Mean & 2.24 & 1.30 & 1.77 \\
\hline Effect & $\mathbf{V}$ & Zn levels & V $\times$ Zn levels \\
\hline S.Em. \pm & 0.52 & 0.24 & 0.73 \\
\hline C.D. $(p \leq 0.05)$ & 1.47 & 0.69 & NS \\
\hline
\end{tabular}


Table.5 Effect of zinc application on number of root tips in cowpea genotypes

\begin{tabular}{|c|c|c|c|}
\hline \multirow{2}{*}{ Genotypes } & \multicolumn{3}{|c|}{ Number of root tips } \\
\cline { 2 - 4 } & $\mathbf{+ Z n}$ & $\mathbf{- Z n}$ & Mean \\
\hline $\mathbf{V 1}$ & 1134.0 & 1445.0 & 1289.5 \\
\hline $\mathbf{V}$ & 1516.5 & 1283.0 & 1399.8 \\
\hline $\mathbf{V 3}$ & 1378.8 & 1111.3 & 1245.0 \\
\hline $\mathbf{V 5}$ & 1093.5 & 1132.3 & 112.9 \\
\hline $\mathbf{V 6}$ & 1752.3 & 1145.8 & 1523.0 \\
\hline $\mathbf{V 7}$ & 1510.8 & 1537.0 & 983.5 \\
\hline $\mathbf{V 9}$ & 1083.8 & 883.3 & 1663.3 \\
\hline $\mathbf{V 1 0}$ & 1342.0 & 1984.5 & 1676.1 \\
\hline V11 & 1648.0 & 1704.3 & 1371.4 \\
\hline Mean & 1384.4 & 1358.5 & $\mathbf{V} \times \mathbf{Z n}$ levels \\
\hline Effect & $\mathbf{V}$ & $\mathbf{Z n ~ l e v e l s}$ & 254.1 \\
\hline S.Em. \pm & 179.7 & 84.7 & NS \\
\hline C.D. $(\mathbf{p} \leq \mathbf{0 . 0 5})$ & NS & NS & \\
\hline
\end{tabular}

Table.6 Effect of zinc application on number of forks in roots of cowpea genotypes

\begin{tabular}{|c|c|c|c|}
\hline \multirow{2}{*}{ Genotypes } & \multicolumn{3}{|c|}{ Number of forks } \\
\hline V1 & $\mathbf{+ Z n}$ & $\mathbf{- Z n}$ & Mean \\
\hline V2 & 7586.0 & 6108.3 & 6847.1 \\
\hline V3 & 6319.3 & 4718.3 & 5518.8 \\
\hline V5 & 6359.0 & 5037.8 & 5398.4 \\
\hline V6 & 5457.3 & 5290.3 & 5814.0 \\
\hline V7 & 5783.0 & 3903.0 & 4680.1 \\
\hline V9 & 5435.5 & 6220.0 & 6001.5 \\
\hline V10 & 6478.8 & 3158.8 & 4297.1 \\
\hline V11 & 6208.5 & 7691.3 & 7085.0 \\
\hline Mean & 6151.7 & 5514.0 & 5861.3 \\
\hline Effect & $\mathbf{V}$ & 5293.5 & 5722.6 \\
\hline S.Em. $\boldsymbol{\pm}$ & 573.8 & $\mathbf{Z n ~ l e v e l s}$ & $\mathbf{V} \times \mathbf{Z n}$ levels \\
\hline C.D. $(\mathbf{p} \leq \mathbf{0 . 0 5})$ & 1627.1 & 270.5 & 811.5 \\
\hline
\end{tabular}


Table.7 Effect of zinc application on number of crossings in roots of cowpea genotypes

\begin{tabular}{|c|c|c|c|}
\hline \multirow{2}{*}{ Genotypes } & \multicolumn{3}{|c|}{ Number of crossings } \\
\cline { 2 - 4 } & $\mathbf{+ Z n}$ & $\mathbf{- Z n}$ & Mean \\
\hline V1 & 1067.0 & 899.8 & 983.4 \\
\hline V2 & 1089.8 & 771.3 & 930.5 \\
\hline V3 & 815.0 & 624.3 & 719.6 \\
\hline V6 & 819.8 & 893.8 & 856.8 \\
\hline V7 & 949.8 & 653.3 & 801.5 \\
\hline V9 & 893.3 & 1074.3 & 983.8 \\
\hline V10 & 890.0 & 542.8 & 716.4 \\
\hline V11 & 1035.5 & 1354.0 & 1194.8 \\
\hline Mean & 1055.3 & 1046.3 & 1050.8 \\
\hline Effect & 957.3 & 873.3 & 915.3 \\
\hline S.Em. $\boldsymbol{\pm}$ & $\mathbf{V}$ & $\mathbf{Z n ~ l e v e l s}$ & $\mathbf{V} \times \mathbf{Z n ~ l e v e l s}$ \\
\hline C.D. $(\mathbf{p} \leq \mathbf{0 . 0 5}$ & 104.3 & 49.1 & 147.4 \\
\hline
\end{tabular}

Table.8 Effect of zinc application on cation exchange capacity (meq. g-1) in roots cowpea genotypes

\begin{tabular}{|c|c|c|c|}
\hline \multirow[t]{2}{*}{ Genotypes } & \multicolumn{3}{|c|}{ Root cation exchange capacity (meq. g $^{-1}$ ) } \\
\hline & $+\mathrm{Zn}$ & $-\mathbf{Z n}$ & Mean \\
\hline V1 & 0.327 & 0.360 & 0.343 \\
\hline V2 & 0.321 & 0.314 & 0.317 \\
\hline V3 & 0.332 & 0.359 & 0.345 \\
\hline V5 & 0.373 & 0.424 & 0.398 \\
\hline V6 & 0.268 & 0.397 & 0.333 \\
\hline V7 & 0.314 & 0.418 & 0.366 \\
\hline V9 & 0.421 & 0.333 & 0.377 \\
\hline V10 & 0.330 & 0.356 & 0.343 \\
\hline V11 & 0.359 & 0.356 & 0.357 \\
\hline Mean & 0.338 & 0.368 & 0.353 \\
\hline Effect & $\mathbf{V}$ & Zn levels & $\mathrm{V} \times \mathbf{Z n}$ levels \\
\hline S.Em. \pm & 0.010 & 0.049 & 0.015 \\
\hline C.D. $(\mathrm{p} \leq \mathbf{0 . 0 5})$ & 0.031 & 0.015 & 0.044 \\
\hline
\end{tabular}


Table.9 Effect of zinc application on root weight per plant $(\mathrm{g})$ in cowpea genotypes

\begin{tabular}{|c|c|c|c|}
\hline \multirow{2}{*}{ Genotypes } & \multicolumn{3}{|c|}{ Root weight per plant (g) } \\
\cline { 2 - 4 } & $\mathbf{+ Z n}$ & $-\mathbf{Z n}$ & Mean \\
\hline V1 & 0.132 & 0.167 & 0.149 \\
\hline V2 & 0.105 & 0.105 & 0.105 \\
\hline V3 & 0.128 & 0.154 & 0.141 \\
\hline V5 & 0.164 & 0.157 & 0.160 \\
\hline V6 & 0.182 & 0.152 & 0.167 \\
\hline V7 & 0.190 & 0.167 & 0.178 \\
\hline V9 & 0.177 & 0.140 & 0.158 \\
\hline V10 & 0.177 & 0.202 & 0.190 \\
\hline V11 & 0.139 & 0.150 & 0.144 \\
\hline Mean & 0.155 & 0.155 & 0.155 \\
\hline Effect & $\mathbf{V}$ & $\mathbf{Z n ~ l e v e l s}$ & $\mathbf{V} \times \mathbf{Z n ~ l e v e l s}$ \\
\hline S.Em. $\mathbf{E}$ & 0.0064 & 0.0030 & 0.0091 \\
\hline C.D. $(\mathbf{p} \leq \mathbf{0 . 0 5})$ & 0.0190 & NS & 0.027 \\
\hline
\end{tabular}

Table.10 Effect of zinc application on shoot weight per plant (g) in cowpea genotypes

\begin{tabular}{|c|c|c|c|}
\hline \multirow[t]{2}{*}{ Genotypes } & \multicolumn{3}{|c|}{ Shoot weight per plant (g) } \\
\hline & $+\mathbf{Z n}$ & $-\mathbf{Z n}$ & Mean \\
\hline V1 & 0.72 & 0.76 & 0.74 \\
\hline V2 & 0.48 & 0.50 & 0.49 \\
\hline V3 & 0.81 & 0.64 & 0.73 \\
\hline V5 & 0.76 & 0.65 & 0.70 \\
\hline V6 & 1.04 & 0.80 & 0.92 \\
\hline V7 & 0.83 & 0.85 & 0.84 \\
\hline V9 & 0.90 & 0.67 & 0.78 \\
\hline V10 & 0.92 & 0.83 & 0.88 \\
\hline V11 & 0.56 & 0.59 & 0.58 \\
\hline Mean & 0.78 & 0.70 & 0.74 \\
\hline Effect & $\mathbf{V}$ & Zn levels & $\mathrm{V} \times \mathrm{Zn}$ levels \\
\hline S.Em. \pm & 0.03 & 0.01 & 0.04 \\
\hline C.D. $(p \leq 0.05)$ & 0.09 & 0.04 & 0.13 \\
\hline
\end{tabular}


Table.11 Effect of zinc application on ratio of dry weight of shoot and root in cowpea genotypes

\begin{tabular}{|c|c|c|c|}
\hline \multirow{2}{*}{ Genotypes } & \multicolumn{3}{|c|}{ Ratio of dry weight of shoot and root } \\
\hline V1 & $\mathbf{+ Z n}$ & $\mathbf{- Z n}$ & Mean \\
\hline V2 & 5.49 & 4.57 & 5.03 \\
\hline V3 & 4.55 & 4.76 & 4.65 \\
\hline V5 & 6.37 & 4.16 & 5.27 \\
\hline V6 & 4.64 & 4.14 & 4.39 \\
\hline V7 & 5.70 & 5.30 & 5.50 \\
\hline V9 & 4.34 & 5.18 & 4.76 \\
\hline V10 & 5.08 & 4.78 & 4.93 \\
\hline V11 & 5.21 & 4.13 & 4.67 \\
\hline Mean & 4.07 & 3.96 & 4.02 \\
\hline Effect & 5.05 & 4.55 & 4.80 \\
\hline S.Em. $\mathbf{\pm}$ & $\mathbf{V}$ & $\mathbf{Z n ~ l e v e l s}$ & $\mathbf{V} \times \mathbf{Z n ~ l e v e l s}$ \\
\hline C.D. $(\mathbf{p} \leq \mathbf{0 . 0 5}$ & 0.20 & 0.09 & 0.28 \\
\hline
\end{tabular}

Longer and thinner roots and a greater proportion of thinner roots were associated with $\mathrm{Zn}$ efficiency in wheat (Dong et al., 1995). The $\mathrm{Zn}$ deficit stress also greatly influenced the activity of root tip cells in cowpea genotypes. Similar to root length; surface area, root volume, number of forks, shoot-dry matter production and dry weight ratio in shoot and root were significantly increased with the application of $\mathrm{Zn}$ over no application of $\mathrm{Zn}$ while average diameter of root, number of root tips, number of crossings in root and root weight was not altered.

Significant shoot-dry matter production was observed in the all nine cowpea genotypes. Genotypes V3, V6 and V9 were most efficient in extracting $\mathrm{Zn}$ from low-Zn growth medium, possibly due to an efficient iontransport system (Grewal et al., 1997 and Khan et al., 1998). The average dry weight ratio in shoot and root was significantly increased in the V1, V3 and V10 genotypes with the application of $\mathrm{Zn}$ over no application of $\mathrm{Zn}$ may which might be due to efficient absorption of $\mathrm{Zn}$ by these genotypes while genotype V7 showed a significant decrease in dry weight ratio of shoot and root. Similarly, for a range of plant species under $\mathrm{Zn}$ deficiency, the root: shoot ratio has been found to increase (Cumbus 1985; Loneragan et al., 1987; Khan et al., 1998). The average root cation exchange capacity of cowpea genotype decreased significantly with the application of $\mathrm{Zn}$ while a close perusal of data regarding the interaction effect of genotypes and $\mathrm{Zn}$ levels revealed that the root cation exchange capacity increased in the V9 genotype while decreased in V5, V6 and V7. Crooke and Knight (1962) made an evaluation of the data of different workers.

They drew an inference that the CEC was positively correlated with the content of the tops of (a) total cations, (b) the ash, (c) the excess base, and (d) the total trace elements. Williams and Coleman (1950) reported that plant root surfaces possessed cation exchange capacities which may be measured by the adsorption and release of various cations. They added that the CEC was the same on live or killed roots which indicated that the CEC on the surface of the root was metabolically inactive. 


\section{References}

Alloway, B.J., 2004. Zinc in Soils and Crop Nutrition. 1st Edn., International Zinc Association (IZA), Brussels, Belgium, pp: 128

Cakmak, I. 2011. Zinc plays critical role in plant growth. http://www.zinc.org/ crops/ resourceserve/zincplays_critical_ role_in_plant_growth. Accessed:17Apr 2011.

Chen, W.R., He, Z.L., Yang, X.E. and Feng, Y. 2009. Zinc efficiency is correlated with rootmorphology, ultrastructure, and antioxidative enzymes in rice, Journal of Plant Nutrition, 32(2): 287305.

Crooke, W.M. and Knight, J.H. 1962. An evaluation of published data on the mineral composition of plants in the light of the cation exchange capacities of their roots. Soil Science, 93:365-373.

Cumbus, I.P. 1985. Development of wheat roots under zinc deficiency. Plant and Soil, 83(2): 313-316.

Dong, B., Rengel, Z. and Graham. R.D. 1995. Root morphology of wheat genotypes differing in zinc efficiency. Journal of Plant Nutrition, 18: 2761-2773.

Grewal, H.S., Stangoulis, J.C.R., Potter, T.D. and Graham, R.D. 1997. Zinc efficiency of oilseed rape (Brassica napus and $B$. juncea) genotypes. Plant and Soil, 191: 123-132.

Gutschick, V.P. 1993. Nutrient-limited growth rates: roles of nutrient-use efficiency and of adaptation to increase uptake rates. Journal of Experimental Botany, 44: 41-52.

Hart, J.J., Norvell, R.M., Welch, L.A., Sullivan and Kochian, L.V. 1998. Characterization of Zinc uptake, binding and translocation in intact seedlings of bread and durum wheat cultivars. Plant Physiology, 118: 219226

Khan, H.R., McDonald, G.K. and Rengel, Z. 1998. Chickpea genotypes differ in their sensitivity to $\mathrm{Zn}$ deficiency. Plant and Soil, 198: 11-18.

Loneragan, J.F. and Webb, M.J. 1987. Translocation and function of zinc in roots. Journal of Plant Nutrition. 10: 1247-1254.

Marschner, H. 1998. Role of root growth, arbuscular mycorrhiza, and root exudates for the efficiency in nutrient acquisition. Field Crops Research, 56: 203-207.

Robson, A. D.1994. Zinc in soils and plants. Springer, New York.

Singh, A.K. and Bhatt, B.P. 2013. Effect of foliar application of zinc on growth and seed yield of late-sown lentil (Lens culinaris).Indian Journal of Agricultural Sciences, 83 (6): 622-6.

Williams, D.E. and Coleman, N.T. 1950. Cation exchange properties of plant root surfaces. Plant and Soil, 2: 243-256.

\section{How to cite this article:}

Santosh Chandra Bhatt, Deepa Rawat and Prakash Chandra Srivastava. 2019. Effect of Zn Application on Root Growth Parameters and Shoot Dry Matter Content of Some Cowpea Genotypes. Int.J.Curr.Microbiol.App.Sci. 8(04): 1338-1349.

doi: https://doi.org/10.20546/ijcmas.2019.804.156 